\title{
'Prata-Anã' banana under irrigation levels, planting densities and bunch trimming
}

\author{
Sergio Luiz Rodrigues Donato ${ }^{1}$, Marcelo Rocha dos Santos ${ }^{2}$, \\ Alessandro de Magalhães Arantes ${ }^{1}$, Ariele Vaz Ramos ${ }^{3}$
}

\begin{abstract}
The objective of this study was to assess the effect of planting densities, irrigation levels and bunch trimming on yield, fruit grading and water-use efficiency (WUE) of 'PrataAnã' banana plants. The following factors were combined in a randomized block design: three irrigation levels (IL) - 50, 75 and 100\% crop evapotranspiration (ETc); four planting densities (PD) - 1,666; 2,083; 2,666 and 3,333 plants $\mathrm{ha}^{-1}$; and two bunch trimming treatments (BT) removal of either one or two hands from the bunch. The treatments were arranged in a split-split plot design. Irrigation level was assigned to main plots, PD to subplots and BT to sub-subplots, with four replicates. Measurements were made in the first production cycle. Removing two hands increased number of leaves, leaf area, leaf area index, fruit weight, fruit diameter, total hand weight and mean hand weight of 'Prata-Anã' banana plants. A plant density population of 3,333 plants ha $\mathrm{a}^{-1}$ combined with an irrigation level at 75\% ETc improves plant development and yield while maintaining fruit size and saving water, regardless of removal of one or two hands from the bunch.
\end{abstract}

Index terms: Musa spp., fruit grading, water-use efficiency

\section{Bananeira 'Prata-Anã' submetida a lâminas de irrigação, densidades de plantio e poda de pencas}

Corresponding author: marcelo.rocha@ifbaiano.edu.br

Received: April 10, 2020 Accepted: July 27, 2020

Copyright: All the contents of this journal, except where otherwise noted, is licensed under a Creative Commons Attribution License.
Resumo - Objetivou-se com este trabalho avaliar a produtividade, a classificação de frutos e a eficiência de uso da água da bananeira 'Prata-Anã' submetida a densidades de plantio, lâminas de irrigação e poda de pencas. O delineamento experimental utilizado foi em blocos casualizados, com três lâminas de irrigação (LI) - 50, 75 e 100\% da evapotranspiração da cultuta (ETc), aplicadas por microaspersão; quatro densidades de plantio (DP) -1.666, 2.083, $2.666 \mathrm{e}$ 3.333 plantas ha $^{-1}$; e duas formas de poda de pencas (PP) - uma e duas pencas; em esquema de parcelas subsubdivididas, com LI nas parcelas; DP nas subparcelas, e PP nas subsubparcelas; com quatro repetições, no primeiro ciclo de produção. A poda de duas pencas aumenta o número de folhas, a área foliar, o índice de área foliar, a massa e o diâmetro dos frutos, a massa total e a massa média das pencas na bananeira 'Prata-Anã'. A densidade de 3.333 plantas ha $^{-1}$ e a lâmina de irrigação de $75 \%$ da ETc proporcionam os melhores resultados para o desenvolvimento da planta, com aumento de produtividade, manutenção da classificação comercial e economia de água, independentemente da poda de pencas.

Termos para indexação: Musa spp., classificação de frutos, eficiência do uso da água.

${ }^{1}$ Professor, D.Sc. in Plant Science, Agriculture Sector, Instituto Federal de Educação, Ciência e Tecnologia Baiano Campus Guanambi. Guanambi, Bahia, Brazil.E-mail: sergio.donato@ifbaiano.edu.br(ORCID:0000-0002-7719-4662); alessandro.arantes@ifbaiano. edu.br (ORCID: 0000-0002-7520-9891)

${ }^{2}$ Professor, D.Sc. in Agricultural Engineering, Agriculture Sector, Instituto Federal de Educação, Ciência e Tecnologia Baiano Campus Guanambi. Guanambi, Bahia, Brazil. E-mail: marcelo.rocha@ifbaiano.edu.br(ORCID: 0000-0003-0896-0359)

${ }^{3}$ Agronomist, graduated from the Instituto Federal de Educação, Ciência e Tecnologia Baiano Campus Guanambi. Guanambi, Bahia, Brazil. E-mail: arielevaz.agro@outlook.com (ORCID: 0000-0003-0551-4943) 


\section{Introduction}

Bananas stand out above the most popular fruits worldwide as a major staple food for millions of people, especially in the tropics. In Brazil, the crop plays a major socioeconomic role where it is grown (FERREIRA et al., 2016).

Brazil is the fourth largest banana producer in the world (ANUÁRIO, 2018), but $98 \%$ of its production is for meeting the country's demand for bananas, which is the highest in the world. Banana agribusiness is a profitable, widespread activity in Brazil (LIMA et al., 2012).

Generally, hands located on the lower portion of the bunch are comprised of smaller fruits, which are usually discarded. As the bunch develops, lower hands compete with upper hands for photoassimilates and nutrients taken up by the plant. Removing bottom hands (bunch trimming) soon after flowering allows the remaining fruits to increase in size; however, due to the fact that smaller fruits are widely accepted in Brazilian markets, only "false hands" should be removed (LICHTEMBERG; LICHTEMBERG, 2011).

Studies on Cavendish bananas (LICHTEMBERG et al., 1991; JULIEN et al., 2001; BUGAUD et al., 2015) have reported the removal of bottom hands leads to increased marketable yields due to changes in sourcesink relations (SALISBURY; ROSS, 2012); however, for 'Prata-Anã' bananas, little research has been conducted to examine whether bunch trimming increases fruit weight growth and fruit grading, especially when associated with other interfering factors. Bunch trimming is known to increase fruit size of the hands left on the bunch and to shorten the period between flowering and harvest of Cavendish bananas (LICHTEMBERG et al., 1991).

Rodrigues et al. (2002) reported that removing the bottom hand of bunches of 'Prata-Anã' bananas resulted in no changes in yield in the first two cycles; however, in the third cycle, increases were observed for mean hand weight, inner fruit diameter, but not for total fruit weight. In working with 'Nanicão' banana, Lichtemberg et al. (1991) observed a heavier hand when the hand right below it had been removed.

Over the past decades, banana production has developed significantly in Brazil due to advances and application of new technologies (LICHTEMBERG; LICHTEMBERG, 2011; FERREIRA et al., 2016). Despite that, there is still room for improvement in banana production systems, such as planting densities, irrigation management and bunch trimming, to increase marketable yield and water-use efficiency (WUE).

Management systems should be improved to reduce banana production costs. Increasing planting density is a usual practice when attempting to raise yields of some banana cultivars (NOMURA et al., 2013). Furthermore, yield-improving strategies, such as increasing planting density, prevent damage from wind and excess radiation, control weeds, improve cooling in banana plantations, reduce soil water evaporation and increase WUE (DONATO et al., 2015). An increased yield, however, should not be obtained to the detriment of physical and chemical quality of fruits.

In the current scenario of water scarcity, according to Donato et al. (2015), increasing WUE is critical to saving water that would otherwise be wasted in irrigated fields worldwide. This can be accomplished by improving irrigation system efficiency, irrigation regime and water management.

Deficit irrigation, higher planting density and bunch trimming are practices that may be implemented into banana production systems with the aim of increasing yields and WUE. Therefore, field experiments should be carried out aimed at obtaining results that can be extrapolated to producers because an ill-informed increase in planting density may negatively affect fruit size. To address this possible outcome, bunch trimming may be used to improve fruit size. The objective of this study was to evaluate the effect of planting densities, irrigation levels and bunch trimming on yield, fruit grading and water-use efficiency of 'Prata-Anã' banana plants.

\section{Material and methods}

The work was carried out on an experimental area at the Instituto Federal Baiano, Campus Guanambi, southwestern Bahia state, Brazil (14 ${ }^{\circ} 13^{\prime} \mathrm{S}, 42^{\circ} 46^{\prime} \mathrm{W}$, and altitude of $545 \mathrm{~m}$ ). The climate is hot, dry semi-arid with mean annual temperature of $25.6{ }^{\circ} \mathrm{C}$. Mean annual precipitation is $680 \mathrm{~mm}$, with rains concentrated from Nov to Mar. Figure 1 shows maximum and minimum temperature, wind speed, relative humidity, rainfall, reference evapotranspiration and how much water was applied to each treatment during the experiment, from Dec 8, 2016 to Jan 11, 2018.

The study was based on assessing 'Prata-Anã' banana (Musa spp. AAB) response in the first production cycle to interactions between planting density, irrigation levels and bunch trimming, so as to define the best yieldimproving, water-saving combination between these three factors. 


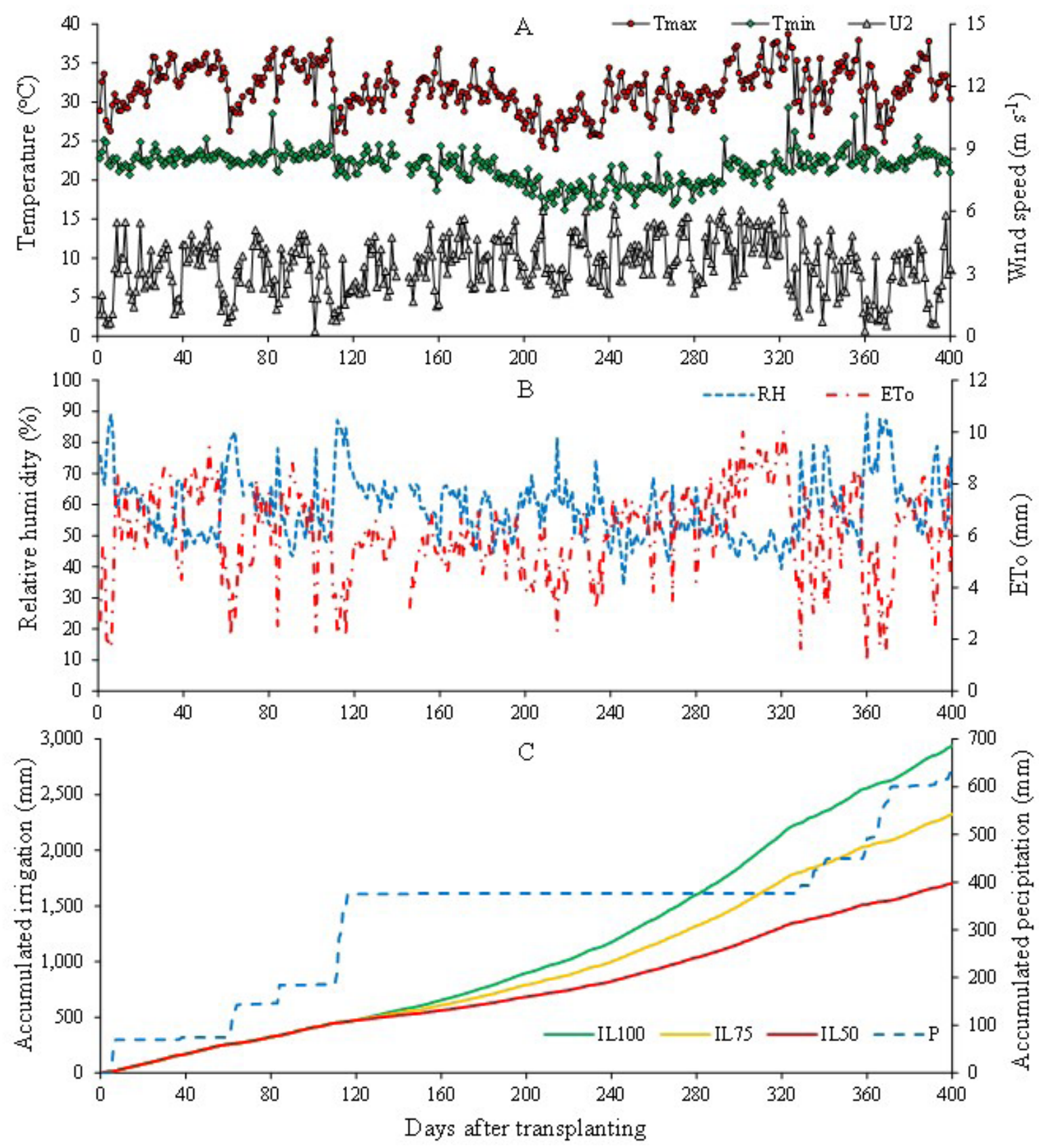

Figure 1. Maximum temperature - Tmax, minimum temperature - Tmin and wind speed - U2 (A); relative humidity RH and reference evapotranspiration - ETo (B); Accumulated irrigation for 100\% ETc - IL100, 75\% ETc- IL75, 50\% ETc - IL50, and accumulated precipitation - P (C) during the experiment. Guanambi, Bahia, Brazil, 2018.

A randomized block design was used, with the following treatments arranged in split-split plots: three irrigation levels, 50, 75 and $100 \%$ crop evapotranspiration $(\mathrm{ETc})$ were assigned to main plots; four planting densities, $1,666(3.0 \mathrm{~m} \times 2.0 \mathrm{~m}), 2,083(3.0 \mathrm{~m} \times 1.6 \mathrm{~m}), 2,666(3.0$ $\mathrm{m} \times 1.25 \mathrm{~m})$ and $3,333(3.0 \mathrm{~m} \times 1.0 \mathrm{~m})$ plants ha- ${ }^{-1}$ to subplots; and two bunch trimming treatments (one or two hands) to sub-subplots. Treatments were replicated four times. Experimental plots consisted of 192 plants, with 16 plants on each subplot. Two plants from each sub-subplot were used for measurements. Subplots were sized in such a way to contain the same number of plants irrespective to planting density.

Uniform, micro-propagated plantlets supplied by Campo Biotecnologia Ltda, located in Cruz das Almas, Bahia state, Brazil, were transplanted when they were 15 cm high. 
Before transplanting, the area was conventionally tilled (subsoiling, plowing and harrowing) and furrows were plowed $3.0 \mathrm{~m}$ apart. Planting holes were dug and spaced apart according to each studied planting density with an auger attached to a tractor. Fertilizers were applied based on soil test results and following Silva (2015) while crop practices followed recommendations of Rodrigues et al. (2015). Chemical properties of the soil before transplanting at $0-20 \mathrm{~cm}$ deep were: $\mathrm{pH}=$ 7.8; soil organic matter $=2.1$ dag kg$~^{-1} ; \mathrm{P}=467.8$ and $\mathrm{K}=$ $598.5 \mathrm{mg} \mathrm{dm}^{-3} ; \mathrm{Na}, \mathrm{Ca}, \mathrm{Mg}$ and $\mathrm{H}+\mathrm{Al}=0.2 ; 5.6 ; 2.5$ and $0.7 \mathrm{cmol}_{\mathrm{c}} \mathrm{dm}^{-3}$, respectively; Effective CEC and CEC at pH $7.0=9.9$ and 10.6, respectively; base saturation, $\mathrm{V}=$ 93.0\%; and electrical conductivity, $\mathrm{EC}=1.7 \mathrm{dS} \mathrm{m}^{-1} ; \mathrm{P}-\mathrm{rem}$ $=46.7 \mathrm{mg} \mathrm{L}^{-1} ; \mathrm{B}, \mathrm{Cu}, \mathrm{Zn}, \mathrm{Fe}$ and $\mathrm{Mn}=0.90 ; 1.20 ; 15.6$; 115.4 and $30.6 \mathrm{mg} \mathrm{dm}^{-3}$, respectively. These results reveal the soil's improved fertility which is a result of fertilizer applications over the last 20 years.

If micronutrient deficiency was detected, fertilizer was applied via foliar applications until the flowering stage. After flowering and in the second production cycle, micronutrient fertilizers were applied via rhizome (removed sucker) (Rodrigues et al., 2007). These fertilizer applications are the reason for the high soil $\mathrm{pH}$.

Plants were irrigated by micro-sprinklers with flow rate of $120 \mathrm{~L} \mathrm{~h}^{-1}$ at an operating pressure of $120 \mathrm{kPa}$. Emitters were spaced $4.0 \mathrm{~m}$ apart within a lateral line while lateral lines were $6.0 \mathrm{~m}$ apart, so application intensity was $5.0 \mathrm{~mm} \mathrm{~h}^{-1}$. The irrigation system was designed to water the whole area because emitters had a 7-m wetted diameter and their application efficiency (KELLER; KARMELI, 1975) was 0.90 from the beginning of the experiment until 190 days after transplanting, and 0.83 from 191 days after planting until the end of the cycle. Irrigation water came from a tubular well and had an electrical conductivity of $0.65 \mathrm{dS} \mathrm{m}^{-1}$.

Irrigation management was based on daily crop evapotranspiration (ETc), which is the product of reference evapotranspiration (ETo) and crop coefficient $(\mathrm{Kc})$. If it rained, the amount precipitated was subtracted from ETc to either correct the plant's water requirement or determine when to irrigate again.

We opted to irrigate plants on a daily basis to provide a better exchange of sensitive heat from banana plants to the water sprayed by emitters, mainly due to high temperatures generally occurring in the region (ARANTES et al., 2018). Crop evapotranspiration was indirectly estimated with the Penman-Monteith equation (ALLEN et al., 1998) using data from a weather station installed near the experimental area. Crop coefficients were calculated based on Equation 1 (BORGES et al., 2011). All plants were fully irrigated during the establishment of the plantation up to a slower, early growth stage, which corresponded to $120 \mathrm{DAP}$. Values ranged from about 0.60 to 1.4 from 120 to $300 \mathrm{DAP}$, when Kc assumed a value of 1.40 until harvest.

$\mathrm{Kc}=0.704-6.443 \times 10-3 \mathrm{DAP}+6.437 \times 10-5 \mathrm{DAP}^{2}-$ $1.174 \times 10-7 \mathrm{DAP}^{3} ; \mathrm{R}^{2}=0.978$

Irrigation levels (IL), in mm, applied to each treatment (Figure 1c), from $120 \mathrm{DAP}$ on, were calculated by $\mathrm{IL}=\mathrm{f} \times \mathrm{ETc} \times \mathrm{K}$, where: $\mathrm{f}=0.5,0.75$ and 1.0 for $50 \%$, $75 \%$ and $100 \% \mathrm{ETc}$ and $\mathrm{Kl}$ is a coefficient representing the wetted portion of the total area available for the plant. As the system was designed to irrigate the whole area, with overlapping wetted areas, $\mathrm{K} 1$ was equal to 1.0 regardless of the treatment.

Bunch trimming was carried out on bunches of measurement plants on sub-subplots following the removal of the male bud, when the last hand was in a horizontal position (RODRIGUES et al., 2015). A fruit from the two last removed hands was kept on the bunch to allow adequate sap flow, which prevents the bunch from drying out.

Number of living leaves - functional leaves with at least half its area undamaged — and total leaf area were measured when harvesting bunches of measurement plants on sub-subplots. Total leaf area (TLA), expressed in square meters, was estimated using a methodology proposed by Zucoloto et al. (2008), Equation 2.

$\mathrm{TLA}=0.5187(\mathrm{~L} \times \mathrm{W} \times \mathrm{N})+9603.5 ; \mathrm{R}^{2}=0.89$

where, $\mathrm{L}$ and $\mathrm{W}$ are length and width of the third leaf, respectively, and $\mathrm{N}$ is the number of living leaves.

Total leaf area was estimated with leaves of a banana mat representative of the cycle under study in all measurement plants on sub-subplots. Then, leaf area index (LAI) was estimated using the equation: $\mathrm{LAI}=\mathrm{TLA} /$ area occupied by the plant $\left(\mathrm{m}^{2} \mathrm{~m}^{-2}\right)$.

At harvest time, the following were measured: total and mean hand weight, number of fruits, number of hands per bunch, fruit weight, lateral fruit diameter (in mm, measured at middle of the fruit with a caliper positioned on the lateral of the fruit), and outer fruit length. Fruit measurements were taken at the central fruit of the outer row of fruits on the second hand (GUIMARÃES et al., 2013). To determine fruit weight, a scale with a maximum capacity of 4,100 $\mathrm{g}$ and resolution of $0.01 \mathrm{~g}$ was used. Hands were classified according to a standard (PBMH; PIF, 2006) for 'Prata-Anã' banana grown in the region. First grade fruits were those with an outer length greater than or equal to $14 \mathrm{~cm}$ and lateral diameter greater than or equal at $32.00 \mathrm{~mm}$; second grade fruits were those with an outer length greater than or equal to $12 \mathrm{~cm}$ and lower than $14 \mathrm{~cm}$, and lateral diameter greater than or equal to 28.57 $\mathrm{mm}$ and lower than $32.00 \mathrm{~mm}$; and fruits for discarding were those with an outer length shorter than $12 \mathrm{~cm}$ and lateral diameter less than $28.57 \mathrm{~mm}$. 
At last, bunch and hand yields were estimated by multiplying the actual harvested population by the initial planting density, for each replicate.

Water use efficiency (WUE - $\mathrm{kg} \mathrm{ha}^{-1} \mathrm{~mm}^{-1}$ ) was estimated by the ratio of actual hand yield $\left(\mathrm{kg} \mathrm{ha}^{-1}\right)$ to total amount of water applied to the treatment $(\mathrm{mm})$ over the first production cycle.

Data on number of days until harvest, number of leaves at harvest, leaf area at harvest, leaf area index, yield, number of hands, number of fruits per hand, mean fruit weight, outer fruit length, lateral fruit diameter and WUE were subjected to Shapiro-Wilk normality test. The data number of days to harvest, number of leaves at harvest, leaf area index and fruit weight were not normally distributed when considering the three factors, irrigation level, planting density and bunch trimming; thus, to become normally distributed, the data were organized in two ways: irrigation level $\mathrm{x}$ bunch trimming interaction irrespective of planting density and for planting density $\mathrm{x}$ bunch trimming interaction irrespective of irrigation level.

All data were subjected to analysis of variance with the aid of SISVAR (FERREIRA, 2011) and, if the triple interaction was significant, response surface models were used to analyze the response of a measured variable to planting densities and irrigation levels for each of the two bunch trimming treatments. In the event of significant double interactions, response surface model was used if the interaction was between irrigation level and planting density. A mean separation test was used for comparing bunch trimming treatments. Regression analysis was conducted for planting densities. In case of interaction between irrigation level and bunch trimming, Tukey test was used at $5 \%$ significance level.

In the absence of significant interactions, the effects of the main factors were studied with regression analysis for planting densities and Tukey test at 5\% significance for bunch trimming and irrigation levels. Models were chosen considering how significant the beta coefficients were on the $t$ test, how high the coefficient of determination was, and how well the model fits the biological phenomenon under study.

\section{Results and Discussion}

\section{Vegetative characteristics}

Number of living leaves at harvest, leaf area and leaf area index were influenced by factors $(p \leq 0.05)$. Total leaf area varied with the factors irrigation level, planting density and bunch trimming. Number of living leaves at harvest was affected by irrigation level $\mathrm{x}$ bunch trimming interaction as well as by planting density independently. Leaf area index was influenced by planting density $x$ bunch trimming interaction and varied independently with bunch trimming.

Number of leaves at harvest was lower when the plants were irrigated with $100 \%$ ETc and had one hand removed from the bunch (Figure 2A). A smaller sink due to the removal of two hands resulted in greater hand weight (Table 1), which may have contributed to the decrease in sink size and number of leaves (SALISBURY; ROSS, 2012). Costa et al. (2012) and Oliveira et al. (2013b) found no influence of irrigation levels on the number of leaves at harvest. After flowering, banana plants cease to sprout leaves and the period between flowering and harvest is characterized by rapid leaf senescence, where dry leaves are removed (DONATO et al., 2006). Damaged leaves may also be a source of yellow Sigatoka; however, the sink's photosynthetic demand, which depends on the weight or number of fruits on the bunch, can either decrease or increase leaf senescence (SALISBURY; ROSS, 2012).
A

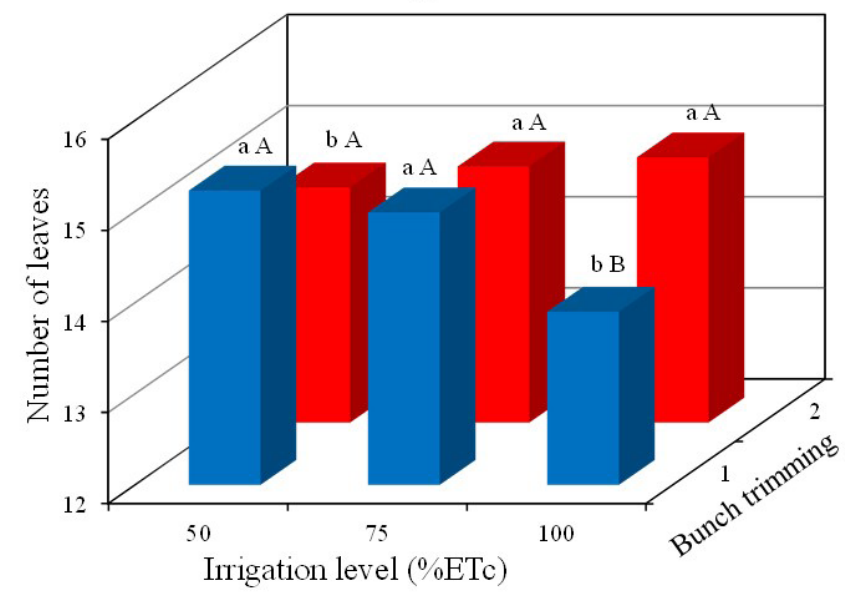

$\mathrm{B}$

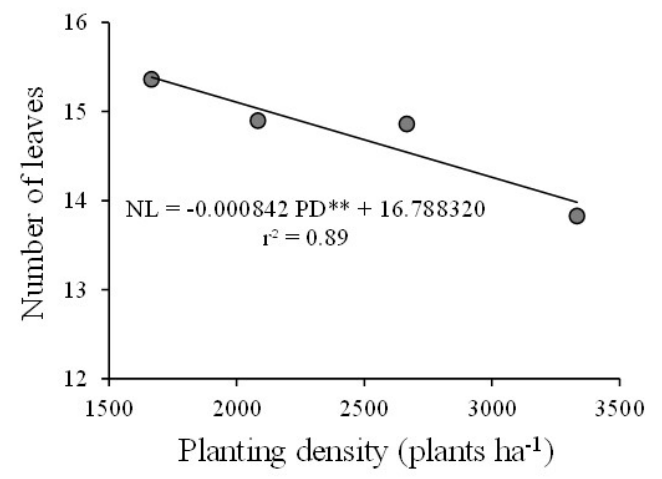

Figure 2. Number of living leaves at harvest of 'Prata-Anã' banana plants in the first production cycle as a function of irrigation levels and bunch trimming treatments (A) and as a function of planting densities (B). Guanambi - BA, Brazil, 2018. Means followed by the same lowercase letter for bunch trimming and the same uppercase letter for irrigation level are not significantly different based on Tukey test at $5 \%$ significance level. ** significance at $1 \%$. 
Table 1. Effect of removing one or two hands from bunches of 'Prata-Anã' banana plants in the first production cycle on the number of hands per bunch, total hand weight, mean hand weight. Guanambi-BA, Brazil, 2018

\begin{tabular}{cccc}
\hline Number of hands removed & $\begin{array}{c}\text { Number of hands per bunch } \\
\text { (unit) }\end{array}$ & $\begin{array}{c}\text { Total hand weight per bunch } \\
(\mathrm{kg})\end{array}$ & Mean hand weight $(\mathrm{kg})$ \\
\hline 1 & $8.08 \mathrm{a}$ & $14.59 \mathrm{~b}$ & $1.80 \mathrm{~b}$ \\
\hline 2 & $7.18 \mathrm{~b}$ & $15.95 \mathrm{a}$ & $2.22 \mathrm{a}$ \\
\hline $\mathrm{CV} \%$ & 7.06 & 15.12 & 16.21 \\
\hline
\end{tabular}

Means followed by the same letter, in the column, do not differ statistically by Tukey test at $5 \%$ significance level.

Number of living leaves at harvest decreased linearly with increasing planting densities (Figure 2B). Each plant had approximately one leaf less for each 1,180 plants added to each hectare. This reduction in the number of leaves is explained by the greater competition for space, water, nutrients and light when the spacing between plants within the row reduces from $2.0 \mathrm{~m}$ to $1.0 \mathrm{~m}$, resulting in an increase in planting density from 1,666 plants ha $^{-1}(3.0$ $\mathrm{m} \times 2.0 \mathrm{~m})$ to 3,333 plants $\mathrm{ha}^{-1}(3.0 \mathrm{~m} \times 1.0 \mathrm{~m})$. In testing planting densities, Pereira et al. (2000) found similar values for the number of leaves; however, the highest planting density used by the authors was 1,666 plant ha $^{-1}$ $(3.0 \mathrm{~m} \times 2.0 \mathrm{~m})$, coinciding with the lowest density used in this study. $\mathrm{TLA}=8.22463+0.05592 \mathrm{IL}-0.0005723 \mathrm{IL}^{2}+0.00227 \mathrm{PD}-7.01 \times 10^{-7} \mathrm{PD}^{2}$
$\mathrm{R}^{2}=0.83$

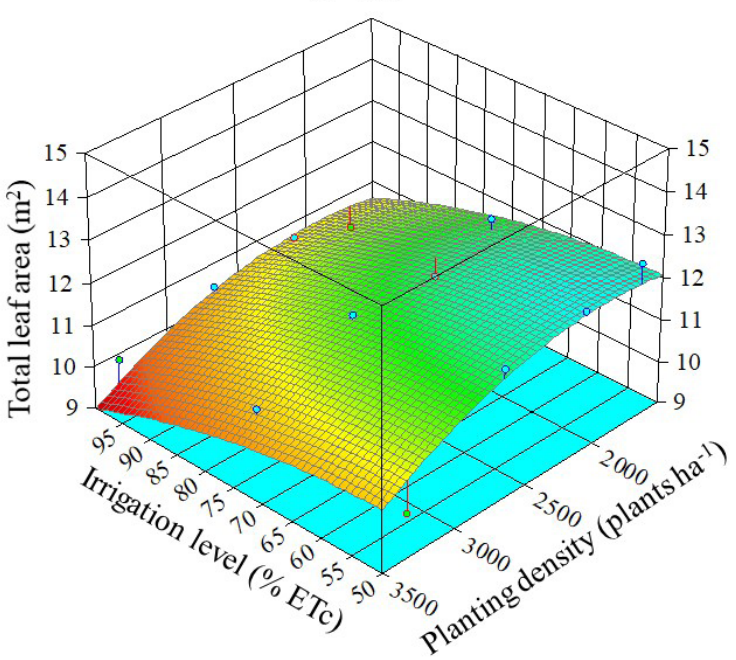

Leaf area at harvest was smaller when a hand was removed from the bunch of fully irrigated plants at the highest planting density, while a greater leaf area was measured at plants irrigated with lower irrigation levels and at the lowest planting density. When removing two hands from the bunch, a larger leaf area was measured at plants under higher irrigation level combined with a lower planting density (Figure 3). The size of the source (leaf area) and the sink (hand weight) are interdependent. Therefore, the removal of two hands (Table 1) contributes to the increase in sink size, which, in turn, increases total leaf area due to the greater availability of water. Photosynthesis, which is dependent on the active photosynthetic area on leaves, is strongly influenced by how demanding the sinks are, with possible renewal of senescent leaves when the sink/source ratio increases substantially. Conversely, large sinks may compete with leaves for nitrogen, leading to decreased size of leaves and, consequently, their photosynthetic capacity reduces (SALISBURY; ROSS, 2012). After flowering, banana plants stop sprouting roots and leaves, decreasing the amount of nutrients taken up by roots; as a result, the translocation of nutrients from older leaves to the bunch becomes predominant.

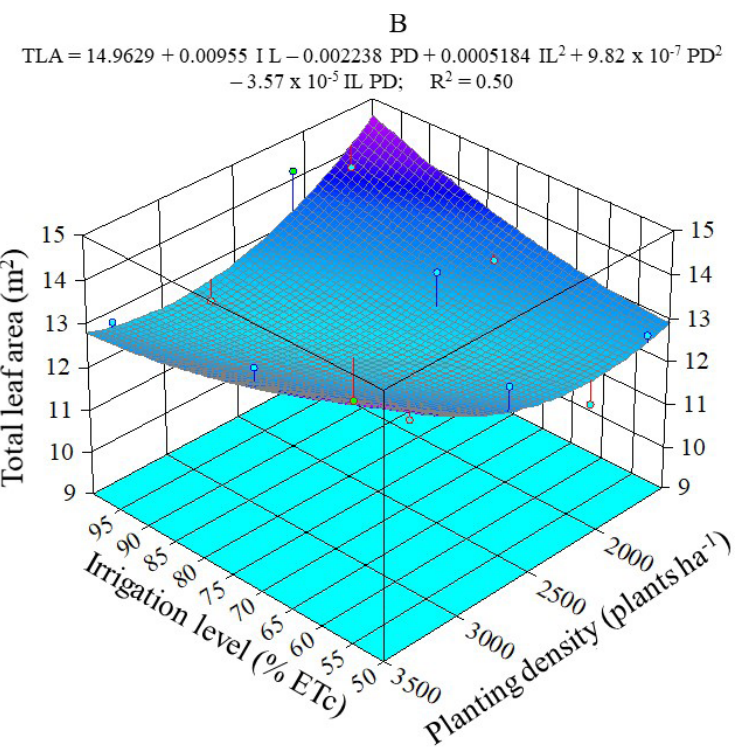

Figure 3. Total leaf area in 'Prata-Anã' banana plants as affected by irrigation level (IL), planting density (PD) with removal of one hand (A) and two hands (B). Guanambi, BA, Brazil, 2018. 
Leaf area index was 3.15 when two hands were removed from the bunch and 2.68 when one hand was removed, differing from each other based on Tukey test ( $p \leq 0.05)$, regardless of irrigation level and planting density. However, there was an interaction effect between planting density and bunch trimming on leaf area index, with a linear upward trend when increasing planting densities. When using greater planting density, the difference between the effect of removing one hand or two hands on mean values of leaf area index was more significant (Figure 4). This indicates that as planting density increases, removing two hands instead of one is the preferable practice. The interplay between sinks and sources (SALISBURY; ROSS, 2012) explains the largest LAI in banana plants with two removed hands.

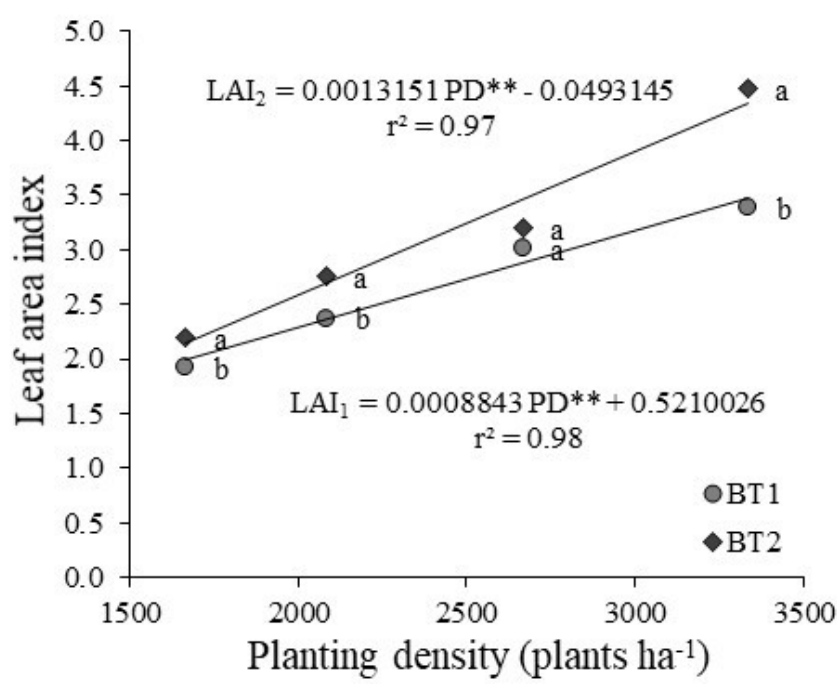

Figure 4. Leaf area index measured when harvesting 'Prata-Anã' banana plants in the first production cycle as a function of planting densities. $\mathrm{LAI}_{1}$ of plants with one removed hand (BT1) or two removed hands (BT2). Guanambi, BA, Brazil, 2018. Means followed by the same letters for each planting density are not significantly different based on the Tukey test at $5 \%$ significance level.

Increasing planting density from 1,666 to 3,333 plants ha ${ }^{-1}$ while removing two hands doubled leaf area index (LAI). In case of removing one hand, the increase in LAI was 1.74 times greater at the highest planting density. A denser plant population reduces the space occupied by a plant. LAI can be estimated by dividing TLA (total leaf area) by the space occupied by plants, so the increase in LAI as a result of increased planting density was expected as the area occupied by plant decreased from $6 \mathrm{~m}^{2}$ at 1,666 plants ha-1 $(3.0 \mathrm{~m} \times 2.0 \mathrm{~m})$ to $3 \mathrm{~m}^{2}$ at 3,333 plants ha-1 $(3.0$ $\mathrm{m} \times 1.0 \mathrm{~m})$.

Banana plants grown at 3,333 plants ha ${ }^{-1}$ with two removed hands had higher LAI, averaging 4.33, which represents more than $90 \%$ of the radiation absorbed on the canopy (TURNER et al., 2007). As for the density of 1,666 plants ha ${ }^{-1}$ with a removed hand, LAI averaged 1.99. This shows that a less dense plant population is more likely to be negatively affected by winds and weeds.

Leaf area indices above 4.5 are of little benefit for the orchard as most incoming radiation is readily intercepted, thereby stunting shaded plants' growth, which leads to yield losses (TURNER et al., 2007).

\section{Yield characteristics}

Number of hands and hand weight were significantly influenced by planting density $\mathrm{x}$ irrigation level interaction as well as by bunch trimming. Naturally, removing one hand resulted in a higher number of hands than removing two hands (Table 1).

On the other hand, removing two hands proved to be more effective in increasing the total hand weight, with a mean weight of $15.95 \mathrm{~kg}$, representing an increase of $3.32 \%$ when compared to the removal of one hand; similarly, mean hand weight was higher when removing two hands $(2.22 \mathrm{~kg})$ instead of one $(1.80 \mathrm{~kg})$ (Table 1). This outcome is justified by the increase in sink size, leaf area and remobilization of photoassimilates (SALISBURY; ROSS, 2012) to the remaining hands, which is evidenced by the higher mean hand weight. Rodrigues et al. (2002) reported a mean hand weight of $1.30 \mathrm{~kg}$; a similar weight was measured in the treatment without hand removal. Goenaga and Irizarry (2006), evaluating the response of two French type plantain clones to bunch trimming, reported a higher hand weight of $2.9 \mathrm{~kg}$ when keeping six hands per bunch. The result is consistent with that of the present study. 
The very last bottom hand, composed of at least $50 \%$ of stunted fruits, also called a "false hand", competes with upper hands for stored carbohydrates and nutrients taken up by the plant. Removing the false hand allows the remaining fruits to develop better, reaching greater weight, length and diameter (LICHTEMBERG et al., 1991), as observed in the present work.

A

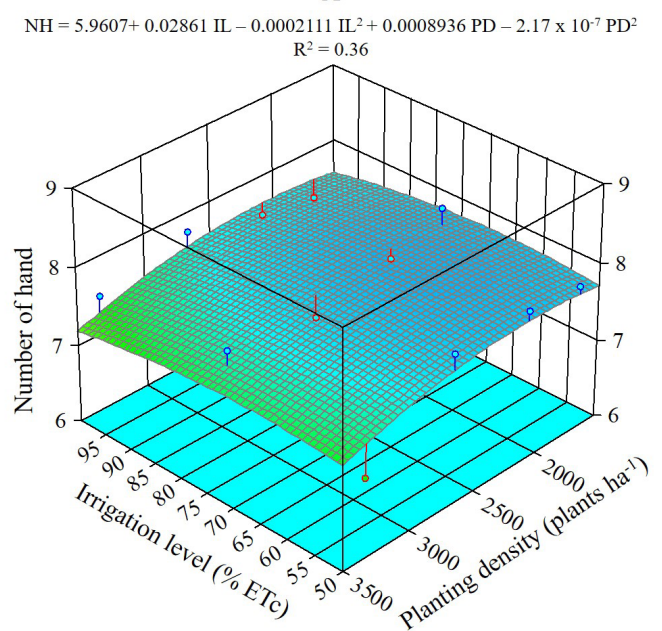

It can be seen in Figure 5 that the number of hands and total hand weight per bunch measured in 'Prata-Anã' bananas decreased with increasing planting densities, peaking at the lowest density $\left(1,666\right.$ plants $\left.\mathrm{ha}^{-1}\right)$. These variables peaked at 68 and $67 \% \mathrm{ETc}(2,000$ and $1,970 \mathrm{~mm})$ with 7.82 hands and $17.05 \mathrm{~kg}$, respectively.

Fruit weight varied independently with irrigation levels, while the number of fruits was influenced by the interactions between bunch trimming and irrigation level, and planting density and irrigation level (Figures 6 and 7).

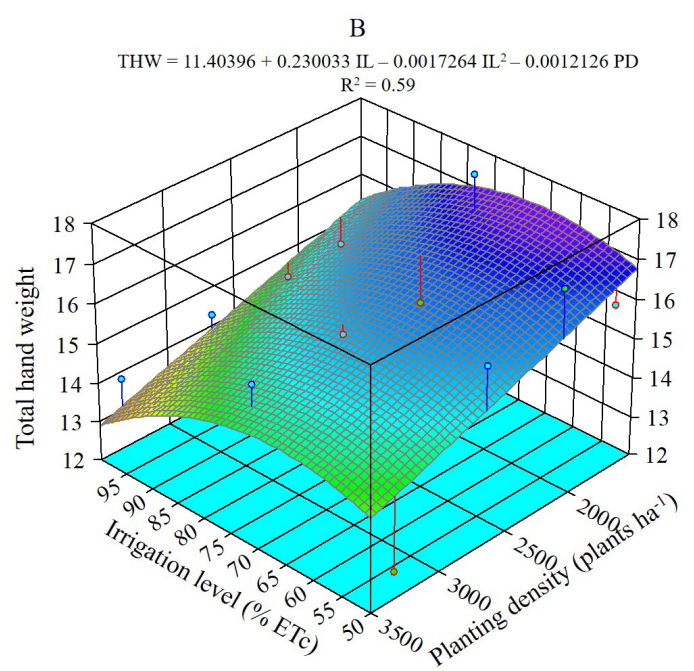

Figure 5. Number of hands (A) and total hand weight (B) per bunch of 'Prata-Anã' banana plants subjected to irrigation levels and planting densities in the first production cycle. Guanambi-BA, Brazil, 2018.

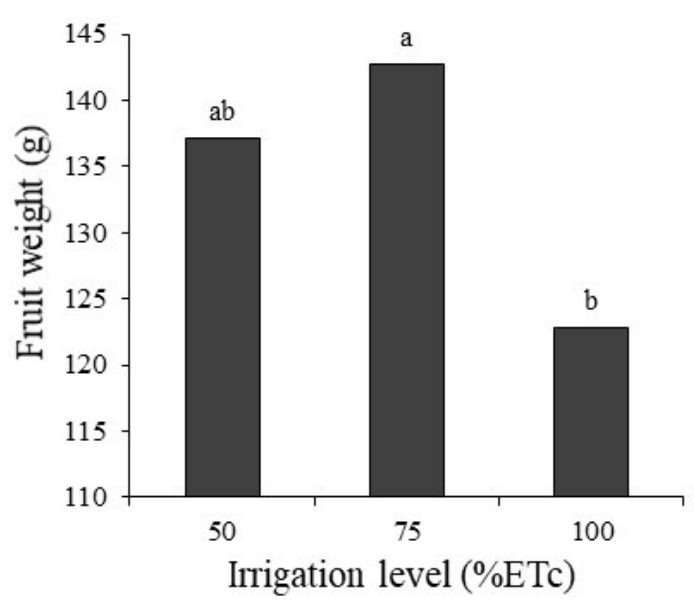

Figure 6. Fruit weight of 'Prata-Anã' banana plants as a function of irrigation level. Guanambi, BA, Brazil, 2018. Means followed by the same letters over the bars do not significantly differ from one another based on Tukey test at 5\% significance level. 
'Prata-Anã' banana plants irrigated with 75\% ETc $(2,323 \mathrm{~mm})$ produced heavier fruits than those irrigated with $100 \% \mathrm{ETc}(2,941 \mathrm{~mm}), 143 \mathrm{~g}$ and $123 \mathrm{~g}$, respectively (Figure 6), regardless of planting densities and bunch trimming practices.

Fruit weight is an important trait for breeding studies; it cannot be considered in isolation but rather associated with other components reflecting the physical quality of fruits, including fruit length and diameter (DONATO et al., 2006; LEDO et al., 2008; OLIVEIRA et al., 2013a).
When considering the interaction between bunch trimming and irrigation level, the number of fruits was lower when plants were irrigated with 50 and $75 \%$ ETc $(1,705 \mathrm{~mm}$ and $2,323 \mathrm{~mm})$ and had two removed hands. Conversely, fruit weight was greater at these two irrigation levels when only one hand is removed from the bunch (Figure 7A). Higher planting densities associated with lower irrigation levels led to fewer fruit on 'Prata-Anã' banana plants, while lower planting densities with greater irrigation levels contributed to a greater number of fruits (Figure 7B). In evaluating the influence of planting densities and irrigation levels on 'BRS Platina' banana, Santos et al (2019) reported a linear increase in the number of fruits, from 89.46 to 98.08 , by increasing irrigation level from $55 \%$ to $100 \%$ of ETc.

A

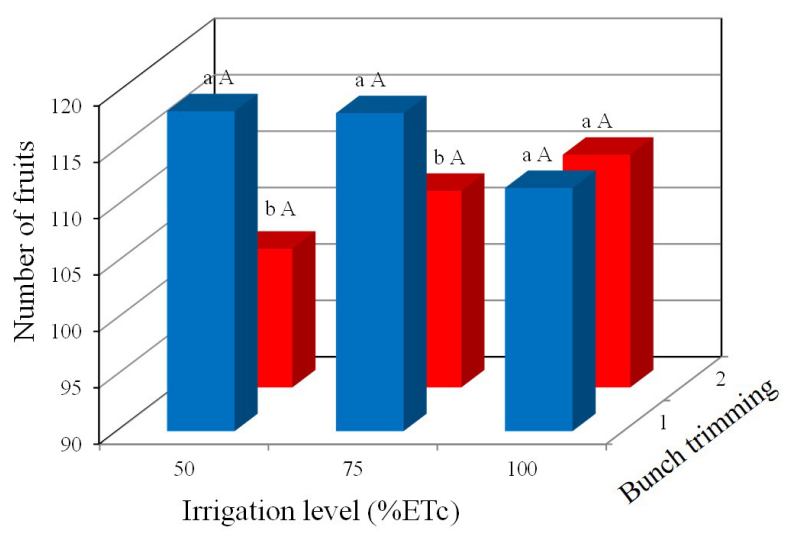

B

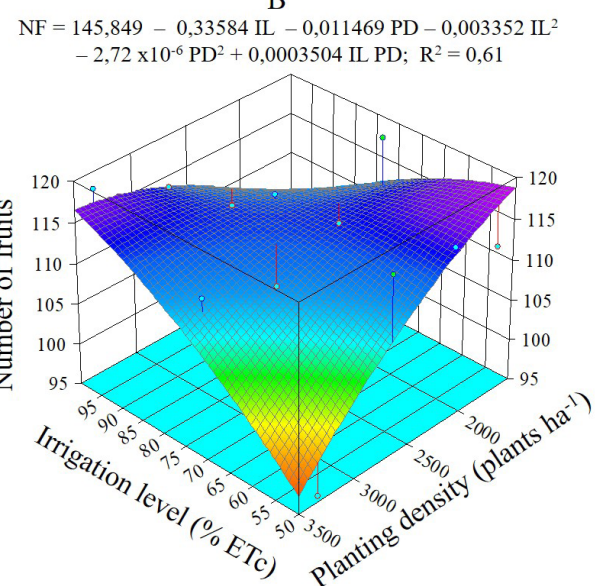

Figure 7. Number of fruits per bunch as a function of irrigation level $\mathrm{x}$ bunch trimming interaction $(\mathrm{A})$ and irrigation level x planting density interaction (B). Guanambi, BA, Brazil, 2018. Means followed by the same lowercase letter for bunch trimming and the same uppercase letter for irrigation level are not significantly different based on Tukey test at $5 \%$ significance level.

Scarpare Filho and Kluge (2001) observed more fruits on bunches harvested from plants at lower densities, which is consistent with the present study. Moreira et al. (2007), however, found no significant difference in the number of fruits between planting densities of 1,$111 ; 1,667$ and 3,333 plants ha ${ }^{-1}$. According to Nomura et al. (2013), the greater spacing between plants allows a better use of light, water and nutrients, which, in turn, improves plant development and fruit yield.
Fruit length was influenced only by irrigation level; 'Prata-Anã' banana plants irrigated with $75 \%$ ETc $(2,323$ $\mathrm{mm})$ produced longer fruits than plants irrigated with $100 \%$ ETc (Figure 8). However, regardless of the irrigation level, no fruit was found to be shorter than $15.73 \mathrm{~cm}$, so all fruits were classified as first grade in terms of length, as compared with the standard (PBMH; PIF, 2006) for 'Prata-Anã' banana grown in the region: first grade fruits are those with length greater than or equal to $14 \mathrm{~cm}$. 


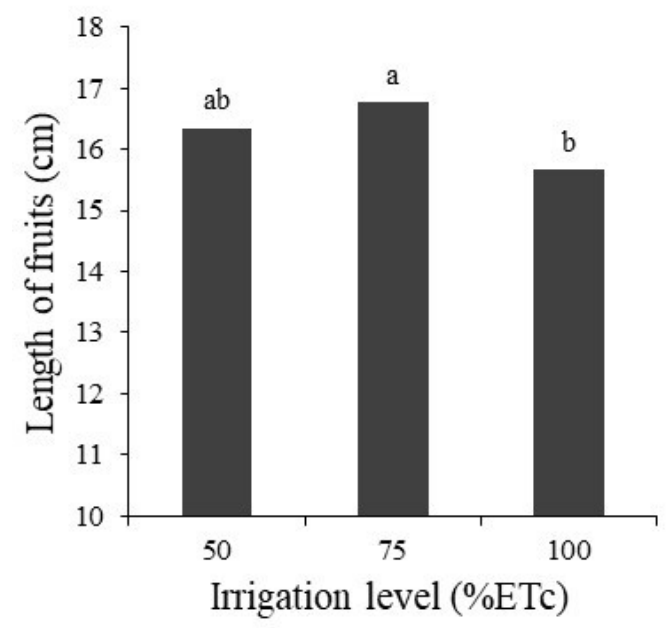

Figure 8. Length of fruits of 'Prata-Anã' banana plants as a function of irrigation level. Guanambi, BA, Brazil, 2018. Means followed by the same letter over bars are not significant different based on Tukey test at 5\% significance level.

Lateral fruit diameter of 'Prata-Anã' banana was influenced by the interaction between irrigation level and bunch trimming (Figure 9A) and independently by planting density (Figure 9B). Plants irrigated with 100\%
ETc and having a removed hand produced fruits with a smaller lateral diameter; however, when irrigating with $75 \% \mathrm{ETc}$, the plants produce fruits with larger diameters, irrespective of how many hands were removed.
A

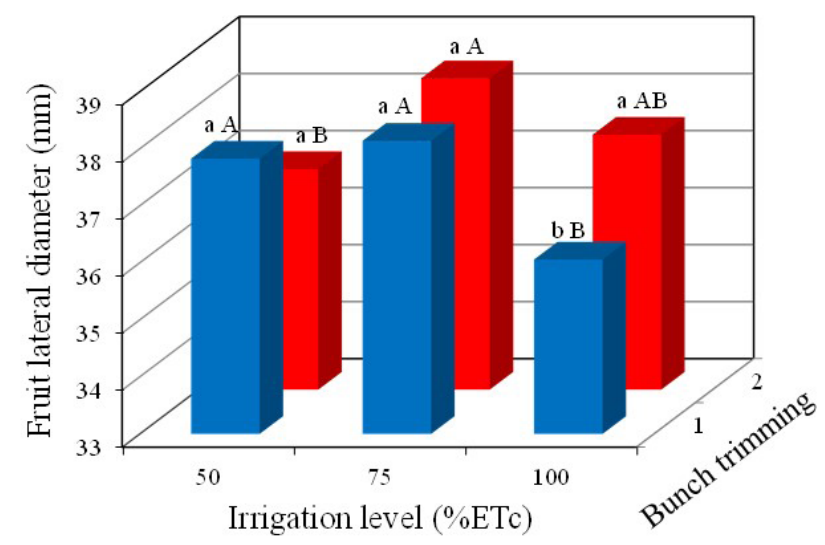

$\mathrm{B}$

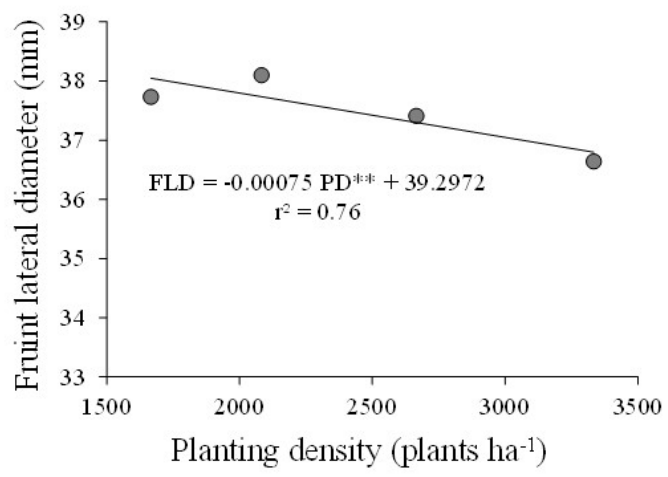

Figure 9. Fruit lateral diameter of 'Prata-Anã' banana as a function of the interactions between irrigation level and bunch trimming (A) and planting density (B). Guanambi, Brazil, 2018. Means followed the same lowercase letter for bunch trimming and the same uppercase letter for irrigation level are not significantly different based on Tukey test at $5 \%$ significance level.

Increasing planting density from 1,666 to 3,333 plants $\mathrm{ha}^{-1}$ resulted in a linear reduction in the lateral diameter of the fruit (Figure 8B), from 38.08 to 36.80 $\mathrm{mm}$. However, produce was classified as first grade fruits (PBMH; PIF, 2006): provided that the outer length is greater than $14.0 \mathrm{~cm}$, the diameter must be greater than or equal to $32.00 \mathrm{~mm}$. Moreira et al. (2007) found a decrease in fruit diameter with increasing planting densities, but the decrease in fruit size was such that the fruits were downgraded for having a diameter below $32 \mathrm{~mm}$, reaching the lowest mean diameter of $28 \mathrm{~mm}$ at 3,333 plants ha $^{-1}$ in the first production cycle.
From a commercial standpoint, decreasing spacing between plants proved to be satisfactory for 'Prata-Anã' banana because fruits remained within the first grade classification, in addition to increasing productivity as more plants were harvested per unit area. This was consistent with Santos et al. (2019) who reported an increase in yield of 'BRS Platina' banana in the first production cycle when increasing planting density from 1,600 plants ha ${ }^{-1}$ to 3,333 plants ha $^{-1}$, without downgrading the commercial classification of fruits. 
Fruit yield of 'Prata-Anã' banana was influenced only by planting density (Figure 10A), while water use efficiency (WUE) was independently affected by irrigation level (Figure 10B) and planting density (Figure 10C).
Increasing planting density resulted in a linear increase in yield (Figure 10A), with a mean yield greater than 43 $\mathrm{tha}^{-1}$, even though both the number and weight of hands decreased (Figure 5).
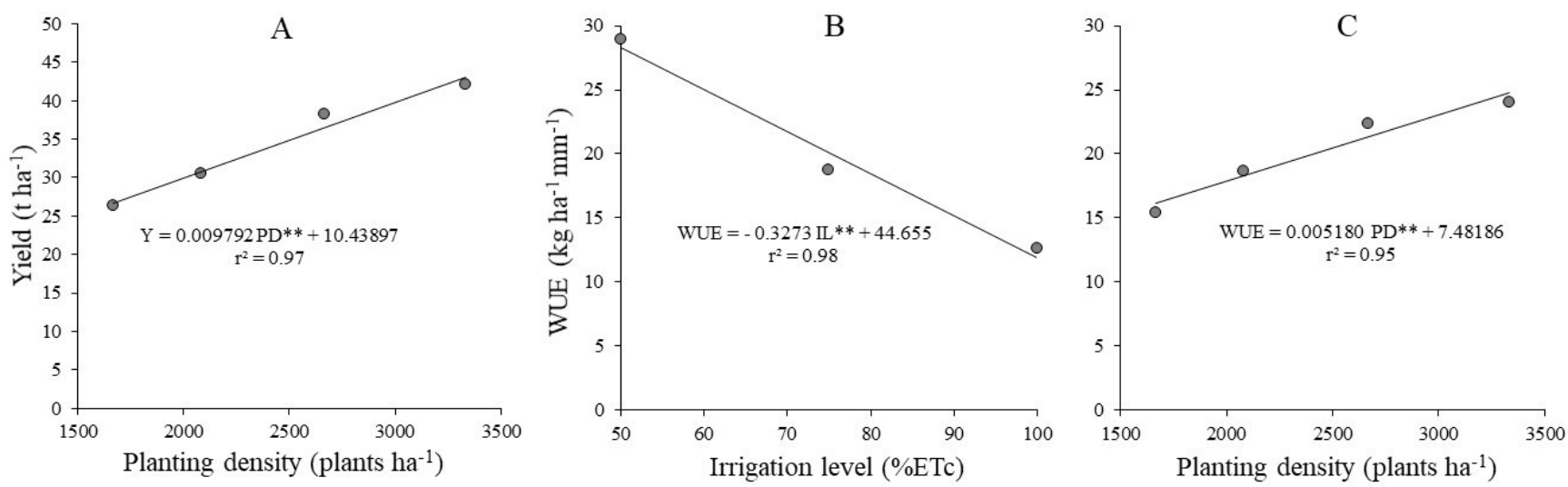

Figure 10. Yield (A), water use efficiency (WUE) of 'Prata-Anã' banana plants in the first production cycle, as a function of irrigation levels (\% ETc) (B) and planting densities (C). Guanambi-BA, Brazil, 2018. ** significant at 1\%.

The gain in fruit weight due to decreased planting density was insufficient to increase overall productivity, causing differences between the highest $\left(3,333\right.$ plants ha $\left.^{-1}\right)$ and the lowest planting density $(1,666$ plants $\left.\mathrm{ha}^{-1}\right)$. Similar results were obtained by Scarpare Filho and Kluge (2001). According to Rodrigues et al. (2015), lower bunch weight and longer production cycle are to be expected when increasing planting density. Some growers choose to plant more densely aiming at increased productivity in the first cycles. This practice is commonly used to increase yield when banana price is higher.

In Venezuela, Martínez et al. (2009) studied the effect of densely planting plantains (AAB) clone Harton on fruit characteristics and yield. The authors reported similar results to those of this study, where an increase in productivity was observed when increasing planting density, with yields of 15.06 and $24.70 \mathrm{t} \mathrm{ha}^{-1}$ at the planting densities 1,100 and 2,916 plants ha ${ }^{-1}$, respectively.

In studying different planting densities in 'Thap Maeo' banana, Moreira et al. (2007) reported an increase in productivity due to increased planting density in the first two production cycles. There was a $160 \%$ increase in productivity from the lowest $\left(1,111\right.$ plants ha $\left.\mathrm{a}^{-1}\right)$ to the highest planting density $\left(3,333\right.$ plants $\left.\mathrm{ha}^{-1}\right)$ in the first production cycle and, for the second cycle, the increase in productivity was $107 \%$ from the lowest to the highest planting density. In the present study, the increase in productivity from the lowest to the highest planting density was $61 \%$. This highlights the importance of an increased planting density.

Water use efficiency decreased linearly with increasing irrigation level (Figure 10B) and increased linearly with increasing planting density (Figure 10C).
This suggests the possibility of obtaining high yields while using water more efficiently by increasing planting density and decreasing the amount of water applied, as reported by Santos et al. (2019) in a similar study on 'BRS Platina' banana.

A smaller spacing between plants may improve yields under the same climate conditions. This is accomplished by, in addition to harvesting more plants per unit area, providing greater shading, reducing soil water evaporation and increasing WUE. However, this is only recommended when physical and chemical quality of produce is maintained (DONATO et al., 2015).

Our results are in consonance with those obtained by Pamponet (2013) who evaluated two planting densities $\left(2,000\right.$ and 4,000 plants ha $\left.^{-1}\right)$ and four irrigation levels $(60,80,100$ and $120 \%$ ETc) in 'Prata-Anã' banana. The authors reported a higher WUE at 4,000 plants ha ${ }^{-1}$, which represented 80 and $85 \%$ increases in yield and 98 and $118 \%$ increases in WUE regardless of how much water was applied when compared with 2,000 plants $\mathrm{ha}^{-1}$ in the second and third cycles, respectively.

When evaluating the influence of planting density and irrigation levels on 'BRS Platina' banana, Santos et al. (2019) found results similar to those reported herein. The authors reported a linear increase in yield and WUE as a result of increasing planting density $(1,600$ to 3,333 plants ha-1). The change was from 5.14 to $8.60 \mathrm{~kg}$ $\mathrm{ha}^{-1} \mathrm{~mm}^{-1}$. As for irrigation levels, the authors reported a decrease from 7.97 to $5.50 \mathrm{~kg} \mathrm{ha}^{-1} \mathrm{~mm}^{-1}$ as irrigation levels increased from $55 \%$ to $100 \%$ ETc, respectively. 


\section{Conclusions}

Removal of two hands may increases number of leaves, leaf area, leaf area index, fruit weight, fruit diameter, total hand weight and mean hand weight of 'Prata-Anã' banana plants.

A planting population of 3,333 plants ha ${ }^{-1}$ combined with an irrigation level at $75 \%$ ETc improves plant development and yield while maintaining fruit size and saving water, regardless of removing one or two hands from the bunch.

\section{References}

ANUÁRIO BRASILEIRO DA FRUTICULTURA 2017. Santa Cruz do Sul : Editora Gazeta Santa Cruz, 2018. 88 p.

ARANTES, A.M.; DONATO, S.L.R.; SIQUEIRA, D.L.; COELHO, E.F. Gas exchange in 'Pome' banana plants grown under different irrigation systems. Engenharia Agrícola, Jaboticabal, v.38, n.2, p.197-207, 2018.

BORGES, A. L.; COELHO, E. F.; COSTA, E. L.; TEIXEIRA, A. H. C. Irrigação e fertirrigação da bananeira. In: SOUZA, V. F.; MAROUELLI, W. A.; COELHO, E. F.; PINTO, J. M.; COELHO FILHO, M. A. (ed.). Irrigação e fertirrigação em fruteiras e hortaliças. Brasília, DF: Embrapa Informação Tecnológica, 2011. p.369-397.

BUGAUD, C.; BELLEIL, T.; TIXIER, P. Modelling the effect of source/sink modifications on pulp dry weight of banana 'Cavendish'. Acta Horticulturae, Leuven, v.1068, p.261-265. 2015.

COSTA, F. S.; COELHO, E. F.; BORGES, A. L.; PAMPONET, A. J. M.; SILVA, A. S. M.; AZEVEDO, N. F. Crescimento, produção e acúmulo de potássio em bananeira 'Galil 18' sob irrigação e fertilização potássica. Pesquisa Agropecuária Brasileira, Brasília, DF, v.47, n.3, p.409-416, 2012.

DONATO, S.L.R.; COLEHO, E.F.; SANTOS, M.R.; ARANTES, A.M.; RODRIGUES, M.G.V. Eficiência de uso da água em bananeira. Informe Agropecuário, Belo Horizonte, v.36, n.288. p. 46-59, 2015.

DONATO, S.L.R.; SILVA, S.O.; LUCCA FILHO, O.A.; LIMA, M.B.; DOMINGUES, H.; ALVES, J.S. Comportamento de variedades e híbridos de bananeira (Musa spp.), em dois ciclos de produção no sudoeste da Bahia. Revista Brasileira de Fruticultura, Jaboticabal, v.28, n.1, p.139-144, 2006.
FERREIRA, D.F. Sisvar: a computer statistical analysis system. Ciência e Agrotecnologia, Lavras, v.35, n.6, p.1039-1042, 2011.

FERREIRA, C.F.; SILVA, S.O.; AMORIM, E.P.; SANTOS-SEREJO, J.A. (ed.). O agronegócio da banana. Brasília, DF: Embrapa, 2016.

GOENAGA, R.; IRRIZARRY, H.J. Yield performance of two French-type plantain clones subjected to bunch pruning. The Journal of Agriculture of the University of Puerto Rico, San Juan, v.90, n.3/4, p.173-182, 2006.

GUIMARÃES, B.V.C.; DONATO, S.L.R.; MAIA, V.M.; ASPIAZÚ, I.; RODRIGUES, M.G.V.; MARQUES, P.R.R. Simple and multiple linear regressions for harvest prediction of Prata type bananas. African Journal of Agricultural Research, Lagos, v.8, n.48, p.6300-6308, 2013.

JULLIEN, A.; MUNIER-JOLAIN, N.G.; MALÉZIEUX, E.; CHILLET, M.; NEY, BERTRAND. Effect of pulp cell number and assimilate availability on dry matter accumulation rate in a banana fruit [Musa sp. AAA group 'Grande Naine' (Cavendish subgroup)]. Annals of Botany. Oxford, v.88, n.2, p.321-330, 2001.

KELLER, J.; KARMELI, D. Trickle irrigation design. Glendora: Rain Bird Sprinkler Manufacturing, 1975. $133 p$.

LEDO, A.S.; SILVA JUNIOR, J.F.S.; LÉDO, C.A.S.; SILVA, S.O. Avaliação de genótipos de bananeira na região do baixo São Francisco, Sergipe. Revista Brasileira de Fruticultura, Jaboticabal, v.30, n.3, p.691-695, 2008.

LICHTEMBERG, L.A.; LICHTEMBERG P.S.F. Avanços na bananicultura brasileira. Revista Brasileira de Fruticultura, Jaboticabal, v.33, n.esp. 1, p.29-36, 2011.

LICHTEMBREG, L.A.; ZAFFARI, G.R.; HINZ, R.H. Experimentos preliminares sobre poda da inflorescência masculina e poda de pencas em banana "Nanicão". Revista Brasileira de Fruticultura, Jaboticabal, v.13, n.1, p.9-18, 1991.

LIMA, M.B., SILVA, S.O., FERREIRA, C.F. (ed.). O produtor pergunta, a EMBRAPA responde. Brasília, DF: Embrapa, 2012. 
MARTÍNEZ, G.; BLANCO. G.; HERNÁNDEZ, J.; MANZANILLA. E.; PÉREZ,A.; PARGAS, P.; MARÍN, C. Comportamiento del plátano (Musa AAB Subgrupo plátano, cv. Hartón Gigante) sembrado a diferentes densidades de siembra en el Estado Yaracuy, Venezuela. Revista UDO Agrícola, Cumana, v.9, p.259-267, 2009.

MOREIRA, A.; HEINRICHS, R.; PEREIRA, J.C.R. Densidade de plantio na produtividade e nos teores de nutrientes nas folhas e frutos da bananeira cv. Thap Maeo. Revista Brasileira de Fruticultura, Jaboticabal, v.29, n.3, p.626-631, 2007.

NOMURA, E.S.; DAMATTO JUNIOR, E.R.; FUZITANI, E.J.; SILVA, S.O.; MORAES, W.S. Desenvolvimento e produção da Bananeira 'Grande Naine' sob diferentes densidades de plantio em região concorrência natural de Sigatoka-Negra. Revista Brasileira de Fruticultura, Jaboticabal, v.35, n.2, p.437-445, 2013.

OLIVEIRA, C.G.; DONATO, S.L.R.; MIZOBUTSI, G.P.; SILVA, J.M.; MIZOBUTSI, E.H. Características pós-colheita de bananas 'Prata-Anã' e 'BRS Platina' armazenadas sob refrigeração. Revista Brasileira de Fruticultura, Jaboticabal, v.35, n.3, p.891-897, 2013a.

OLIVEIRA. J.M.; COELHO FILHO, M.A.; COELHO, E.F. Crescimento da bananeira Grande Naine submetida a diferentes lâminas de irrigação em tabuleiro costeiro. Revista Brasileira de Engenharia Agrícola e Ambiental, Campina Grande, v.17, n.10, p.1038-1046, 2013 b.

PAMPONET, A.J. Resposta da bananeira irrigada com diferentes densidades de plantas. 2013. 111 f. Dissertação (Mestrado) - Universidade Federal do Recôncavo da Bahia, Cruz das Almas, 2013.

PBMH; PIF - Programa Brasileiro para a Modernização da Horticultura e Produção Integrada de Frutas. Normas de classificação de banana. São Paulo: CEAGESP, 2006. (Documentos, 29).

PEREIRA, M.C.T.; SALOMÃO, L.C.C.; SILVA, S.O.; SEDIYAMA, C.S.; COUTO, F.A.A.; SILVA NETO, S.P. Crescimento e produção de primeiro ciclo de bananeira 'Prat-Anã' (AAB) em sete espaçamentos. Pesquisa Agropecuária Brasileira, Brasília, DF, v.35, n.7, p.13771387, 2000.
RODRIGUES, M.G.V.; DONATO, S.L.R.; LICHTEMBERG, L.A.; DIAS, M.S.C. Implantação e condução do bananal. Informe Agropecuário, Belo Horizonte, v.36. n.288. p.27-44, 2015.

RODRIGUES, M.G.V.; RUGGIERO, C.; NATALE, W.; PACHECO, D.D. Nutrição e produção da bananeira 'Prata-Ana' adubada com zinco e boro diretamente no rizoma, via muda desbastada. Revista Brasileira de Fruticultura, Jaboticabal, v.29, n.3, p.645-651, 2007.

RODRIGUES, M.G.V.; SOUTO, R.F.; MENEGUCCI, J.L.P. Efeito da poda da última penca do cacho da bananeira Prata-Anã (AAB) irrigada na produção de frutos no Norte de Minas Gerais. Revista Brasileira de Fruticultura, Jaboticabal, v.24, n.1, p.108-110, 2002.

SALISBURY, F. B.; ROSS, C. W. Fisiologia das plantas. 4.ed. São Paulo: Cencage Learning, 2012. 774 p.

SANTOS, M.R.; DONATO, S.L.R.; MAGALHAES, D.B.; COTRIM, M.P. Precocity, yield and water-use efficiency of banana plants under planting densities and irrigation depths, in semiarid region. Pesquisa Agropecuária Tropical, Goiânia, v.49, p.e53036, 2019.

SILVA, J.T.A. Solo, adubação e nutrição para bananeira. Informe Agropecuário, Belo Horizonte, v.36, n.288, p.74-83, 2015.

SCARPARE FILHO, A.; KLUGE, A. Produção da bananeira 'Nanicão' em diferentes densidades de plantas e sistemas de espaçamento. Pesquisa Agropecuária Brasileira, Brasília, DF, v.36, n.1, p.105-113, 2001.

TURNER, D.W.; FORTESCUE, J.A.; THOMAS, D.S. Environmental physioloy of the bananas (Musa spp.). Brazilian Journal of Plant Physiology, Campos dos Goytacazes, v.19, n.4, p.463-484, 2007.

ZUCOLOTO, M.; LIMA, J.S.S.; COELHO, R.I. Modelo matemático para estimativa da área foliar total de bananeira 'Prata-Anã'. Revista Brasileira de Fruticultura, Jaboticabal, v.30, n.4, p.1152-1154, 2008. 